\title{
Design, synthesis, biological evaluation, and nitric-oxide release studies of a novel series of celecoxib prodrugs possessing a nitric-oxide donor moiety
}

\author{
Wael Mohamed Soliman ${ }^{1,2 *}$, Khaled Rashad Ahmed Abdellatif ${ }^{3,4}$, Edward Elmer Knaus ${ }^{5}$
}

\begin{abstract}
${ }^{\prime}$ Department of Pharmaceutical Sciences, College of Clinical Pharmacy, King Faisal University, Al-Ahsaa, Saudi Arabia, ${ }^{2}$ Department of Medicinal Chemistry, Pharmaceutical Industries Research Division, National Research Centre, Cairo, Egypt, ${ }^{3}$ Pharmaceutical Organic Chemistry Department, Faculty of Pharmacy, Beni-Suef University, Beni-Suef, Egypt, ${ }^{4}$ Pharmaceutical Sciences Department, Ibn Sina National College for Medical Studies, Jeddah, Kingdom of Saudi Arabia, ${ }^{5}$ Faculty of Pharmacy and Pharmaceutical Sciences, University of Alberta, Edmonton, Alberta, Canada
\end{abstract}

\begin{abstract}
A new group of hybrid nitric oxide-releasing anti-inflammatory drugs (NONO-coxibs), in which an $\mathrm{O}^{2}$-acetoxymethyl-1-( $N$-ethyl- $N$-methylamino)diazen-1-ium-1,2-diolate NO-donor moiety is attached directly to the carboxylic acid group of 1-(4-aminosulfonylphenyl)-5-aryl-1H-pyrazol-3-carboxylic acids $(\mathbf{6 a}-\mathbf{c})$, were synthesized. A low amount of NO was released from the diazen-1-ium-1,2-diolate compounds 6a-c upon incubation with phosphate buffer saline (PBS) at pH 7.4 (range: $\mathrm{pH} 7.97-8.51$ ), whereas, the percentage of NO released was significantly higher $(84.5 \%-85.05 \%$ of the theoretical maximal release of two molecules of $\mathrm{NO} /$ molecule of the parent hybrid ester prodrug) when the diazen-1-ium-1,2-diolate ester prodrugs were incubated in the presence of rat serum. These incubation studies demonstrated that both NO and the anti-inflammatory 1-(4-aminosulfonylphenyl)-5-(4-H, 4-F or 4-Me-phenyl)-1H-pyrazol-3-carboxylic acid (4a-c) would be released from the parent NONO-coxib upon in vivo cleavage by non-specific serum esterases. The parent compounds 4 a-c displayed good antiinflammatory effects $\left(\mathrm{ID}_{50}=81.4-112.4 \mathrm{mg} / \mathrm{kg}\right.$ p.o. .) between those exhibited by the reference drugs, aspirin $\left(\mathrm{ID}_{50}=114.3 \mathrm{mg} / \mathrm{kg}\right.$ p.o. $)$ and celecoxib $\left(\mathrm{ID}_{50}=12.6 \mathrm{mg} / \mathrm{kg}\right.$ p.o. $)$. Hybrid ester anti-inflammatory $/ \mathrm{NO}$-donor prodrugs (NONO-coxibs) offer a potential drug-design concept directed toward the development of antiinflammatory drugs that are lacking adverse ulcerogenic and/or cardiovascular effects.
\end{abstract}

Keywords: Anti-inflammatory/development/drugs. NONO-coxib esters. 1,5-dihydropyrazoles.

\section{INTRODUCTION}

Non-steroidal anti-inflammatory drugs (NSAIDs) represent a miscellaneous group of compounds that are essentially used to combat fever, pain, and inflammation. NSAIDs remain by far among the most commonly used classes of medications, accounting for $2.5 \%$ of all prescription dollars in the world (Trelle et al., 2011). NSAIDs exert their pharmacological action by inhibiting the synthesis of prostaglandins (PGs) by non-selectively blocking cyclooxygenases (COX)-1 and COX-2, or by selectively blocking COX-2. (Laine, 2002; Gunter et al.,

\footnotetext{
*Correspondence: W. M. Soliman. Department of Pharmaceutical Sciences, College of Clinical Pharmacy, King Faisal University, Al-Ahsaa 31982, Saudi Arabia, Department of Medicinal Chemistry, Pharmaceutical Industries Research Division, National Research Centre, Cairo, Egypt. Tel.: +966566365244. E-mail address: wsoliman@kfu.edu.sa
}

2017). COX-1 is constitutively expressed in many tissues, and it physiologically functions in the maintenance of renal function, the protection of gastric mucosa, and the regulation of platelet aggregation, while COX-2 is inducible by pro-inflammatory mediators (Gunter et al., 2017). The use of NSAIDs that selectively inhibit the inducible COX-2 isozyme in the periphery provided a useful drug-design concept. This discovery resulted in the development of effective anti-inflammatory (AI) drugs that were devoid of adverse cardiovascular effects and gastrointestinal ulcerogenicity believed to be associated with inhibition of the constitutive cyclooxygenase isoform (COX-1) (Thomsen et al., 2006). Therefore, COX-2 selective inhibitors (coxibs), such as celecoxib, I, rofecoxib, II, and valdecoxib, III, (Figure 1) were developed for the long-term treatment of patients suffering from chronic pain and inflammation (Turini, DuBois, 
2002). Unfortunately, some selective COX-2 inhibitory drugs that include rofecoxib II and valdecoxib III alter the natural balance in the COX biochemical pathway. In this regard, the amount of desirable vasodilatory and antiaggregatory prostacyclin (PGI2) produced is decreased, and this is accompanied by a simultaneous increase in the level of the undesirable prothrombotic thromboxane A2 (TxA2) (Hinz, Brune, 2002; Patel, Gross, 2002). These two adverse biochemical changes in the COX pathway are believed to be responsible for increased incidences of high blood pressure and myocardial infarction that ultimately prompted the withdrawal of rofecoxib, II and valdecoxib, III (Scheen, 2004; Dogné, Supuran, Pratico, 2005).

Nitric oxide (NO) displays a number of favorable pharmacological actions that include vascular relaxation (vasodilation) and inhibition of platelet aggregation and adhesion (Serafim et al., 2012). Brueggeman et al.(2009) found that celecoxib, but not rofecoxib, dilated preconstricted small mesenteric arteries. The authors attributed the vasodilatory activity of celecoxib to the enhancement of KCNQ potassium currents and the suppression of L-type voltage-sensitive calcium currents. NO was shown to exhibit some of the general properties of PGs within gastric mucosa, and thus it should augment the local mucosal defense mechanism, thereby compensating the reduced gastric PGs produced by NSAIDs (Vannini et al., 2015).

The last decade has seen an excessive development of NO-based hybrid drugs in which an appropriate NOreleasing chemical moiety was linked to the parent-already marketed - drugs to refine the overall pharmacotherapeutic efficacy, as well as to reduce any related noxious effects (Serafim et al., 2012; Consalvi, Biava, Poce, 2015; Abdellatif et al., 2017). In vivo and in vitro studies on NO-aspirin displayed more potent antithrombic properties when compared to aspirin. Furthermore, in an animal model of chronic neurodegenerative disease, NO-flurbiprofen and NO-aspirin incapacitated the brain's inflammatory response (Shinde, Modi, Kulkarni, 2017). In 2011, Abdellatif and co-workers (Abdellatif et al., 2011) disclosed the anti-inflammatory and vascular-relaxing activity of a series of diazen-1-ium-1,2-diolated NO donor ester prodrugs of 3-(4-hydroxymethylphenyl)4-(4-methanesulfonylphenyl)-5H-furan-2-one. Other new perspectives of NO donor molecules, including cardioprotectives, have been discussed in a recent study in which the researchers revealed the molecular mechanism of NO action on blood vessels (Kruzliak, Kovacova, Pechanova, 2013; Martelli et al., 2013; Kruzliak, Novák, Novák, 2014). In 2014, Martinez et al. patented a series of NO-releasing guanidine coxibs capable of releasing NO through an enzymatic pathway involving the guanidine moiety while retaining the scaffold of celecoxib (Martinez et al., 2014). Furthermore, Kontrek et al. have revealed that the conjugation of celecoxib with an NO donor moiety retains the anti-inflammatory properties of the parent drug while improving cardiovascular safety and antitumor efficacy, which is in line with other drugs of the NO-NSAIDS class (Konturek et al., 2006). In another study by Knaus et al., the non-ulcerogenic NONO-NSAID ester prodrugs of aspirin (IV) and indomethacin (V) (Figure 1) that have an NO-donor diazen-1-ium-1,2diolate (NONOate) moiety that are effectively cleaved by esterases to release the AI drug and NO, were reported (Velázquez et al., 2008). Therefore, the attachment of a NO-donor moiety to highly selective COX-2 inhibitors (NONO-coxibs) offers a potential drug-design concept that can be leveraged to outwit adverse cardiovascular events (Martelli et al., 2013).

Diazen-1-ium-1,2-diolate ions, after their cleavage from the parent hybrid NONO-coxib, can release up to two equivalents of $\mathrm{NO}$ without further metabolic activation. These ions are structurally diverse and they possess a rich derivatization chemistry that facilitates delivery of NO to specific organ and/or tissue sites (Keefer, 2003). These features distinguish the NONO-coxib IV and V (Figure 1) from nitrate-based NO-coxibs (NMI-1093, Figure 1), which require redox activation before NO is released (Dhawan et al., 2005).

Accordingly, the attachment of a $N$-diazen-1-ium1,2-diolate moiety offers a potential drug-design concept to circumvent the adverse cardiovascular events associated with the chronic clinical use of highly selective COX-2 inhibitors.

\section{RESULTS AND DISCUSSION}

ACOX-2 pharmacophore, such as methanesulfonyl, sulfonamide, methanesulfonamide, azido, or tetrazole, is required at the $\mathrm{R}^{1}$ position on the $N^{1}$-phenyl ring for potent and selective COX-2 inhibitory activity (Zarghi et al., 2011; Zarghi et al., 2012). Studying the CYP2C9 structure-metabolism relationships to optimize the metabolic stability of COX-2 inhibitors, Ahlstrom et al. revealed that the pyrazole ring $\mathrm{C}-3$ position $\left(\mathrm{R}^{2}\right.$ substituent) imposes very few steric restrictions pertaining to COX-2 inhibitors, implying that the inhibitory properties of the COX-2 isozyme should be retained (Ahlström et al., 2007). It was also disclosed that the $\mathrm{R}^{2}$ carboxyl substituent at the $\mathrm{C}-3$ position containing compounds may undergo an electrostatic interaction with Arg120 in the binding pocket of the COX-2 enzyme. The 


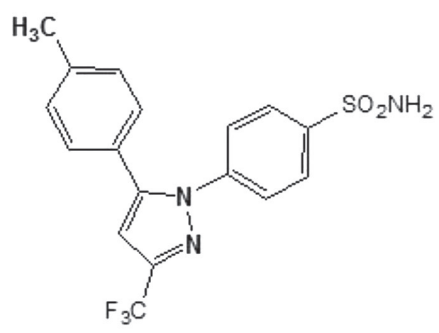

Celecoxib (I)<smiles>[R]OC(=O)c1ccccc1OC(C)=O</smiles>

IV<smiles>Cc1ccc(C2=C(c3ccc(S(N)(=O)=O)cc3)COC2=O)cc1</smiles>

Rofecoxib (II)<smiles>COc1ccc2c(c1)c(CC(=O)O)c(C)n2C(=O)c1ccc(Cl)cc1</smiles>

V<smiles>Cc1ccc(-c2cc(C(F)(F)F)nn2-c2ccc(O)cc2)cc1</smiles>

Valdecoxib (III)

FIGURE 1 - Chemical structure of the selective COX-2 inhibitors celecoxib (I), rofecoxib (II), and valdecoxib (III), diazen-1-iumdiolate ester prodrugs of Aspirin (IV) and indomethacin (V), and nitrate-based prodrug (NMI-1093).

$\mathrm{R}^{3}$ methyl substituent (benzylic carbon) in celecoxib (see the structure in Figure 2) undergoes sequential metabolic biotransformation to inactive metabolites;

$\mathrm{Me} \rightarrow \mathrm{CH}_{2} \mathrm{OH} \rightarrow \mathrm{CO}_{2} \mathrm{H} \rightarrow \mathrm{CO}_{2}$ glucuronide conjugate) thus, it was concluded that the $\mathrm{R}^{3}$ carboxyl substituent on the pyrazole C-5 phenyl ring was not tolerable (Abdellatif et al., 2009). Based on this structural information, it was decided that the $O^{2}$-acetoxymethyl-1-( $N$-ethyl- $N$ methylamino) diazen-1-ium-1,2-diolate NO-donor moiety be coupled to a pyrazole ring from the $\mathrm{C}-3 \mathrm{CO}_{2} \mathrm{H}$ group via an ester moiety to prepare the target NONO-coxib hybrid ester prodrugs $(\mathbf{6 a}-\mathbf{c})$.

The percentage of NO released from the hybrid ester prodrugs $(\mathbf{6 a}-\mathbf{c})$ upon incubation in phosphate buffered saline (PBS; pH 7.4), and in the presence of rat serum, was calculated (see data in Table I). One type of chemical modification was used to control the rate of NO release from diazen-1-ium-1,2-diolate; this is the attachment of alkyl substituents to the $\mathrm{O}^{2}$-position (Huang et al., 2012). $O^{2}$-substituted-diazen-1-ium-1,2-diolates are stable compounds that hydrolyze slowly, even in an acidic solution (Hrabie et al., 1993). Consistent with these observations, when compounds $\mathbf{6 a}-\mathbf{c}$ were incubated for 1.5 hours in PBS at $\mathrm{pH} 7.4$, the percentage of NO released varied from $7.97 \%$ to $8.51 \%$, suggesting slow NO release.
Conversely, the effect of non-specific esterases present in rat serum was higher (range: $65.9 \%-74.0 \%$ ). These data indicate that the non-specific serum esterases present in rat serum cleave these hybrid prodrug esters more effectively than PBS at $\mathrm{pH}$ 7.4. The hybrid ester prodrugs $\mathbf{6 a}-\mathbf{c}$ cannot release NO prior to cleavage of the acetoxy moiety present in the terminal $O^{2}$-acetoxymethyl-1- $(N$ methylamino)diazen-1-ium-1,2-diolate NO-donor moiety. This requirement is consistent with the observation that the $O^{2}$-sodium diazen-1-ium-1,2-diolate, which does not possess an ester group that requires prior ester cleavage, releases $84.5 \%$ and $85.0 \%$ of the theoretical maximal release of two molecules of NO and the molecule of the parent NO donor, respectively, as disclosed earlier (Abdellatif et al., 2008). An earlier study revealed that there are two possible pathways for the ester hydrolysis of hybrid ester prodrugs containing an $O^{2}$-acetoxymethyl-1[N-(2-ethoxy)- $N$-methylamino] diazen-1-ium-1,2-diolate moiety. Moreover, the study described the subsequent release of acetic acid, formaldehyde, two molecules of NO, and $N$-methylethanolamine (Velázquez et al., 2007). The hybrid ester NO-donor prodrugs $\mathbf{6 a}-\mathbf{c}$ were designed with a one-carbon methylene spacer between the terminal acetoxy group and the diazen-1-ium-1,2-diolate $\mathrm{O}^{2}$-atom, such that the $\mathrm{O}^{2}$-(hydroxymethyl)diazen-1- 
ium-1,2-diolate compound formed following cleavage of the acetoxy group; this would spontaneously eliminate formaldehyde to produce the free diazen-1-ium-1,2-diolate compound that can subsequently fragment to release two molecules of NO. Contrariwise, cleavage of the second ester group attached directly to the $\mathrm{C}-3$ position of the pyrazole ring, which releases the parent coxib $4 \mathbf{a}-\mathbf{c}$, can occur either prior to or after NO release has occurred. The NO release properties of compounds $\mathbf{6 a}-\mathbf{c}$ were significant. Compounds $\mathbf{4 a}-\mathbf{c}$ exhibited AI activities $\left(\mathrm{ID}_{50}=85.2-104.4 \mathrm{mg} / \mathrm{kg}\right.$ p.o. range) between those exhibited by the reference drugs, aspirin $\left(\mathrm{ID}_{50}=128.7 \mathrm{mg} / \mathrm{kg}\right.$ p.o.) and celecoxib ( $\mathrm{ID}_{50}=10.8 \mathrm{mg} / \mathrm{kg}$ p.o. $)$. The relative potency profile relative to the R-substituent was $\mathrm{Me}>\mathrm{F} \approx \mathrm{H}$. These AI data are aligned with the COX inhibition assay data, in which the prodrug with the $\mathrm{R}=$ Me displayed the highest COX-2 selectivity (SI) toward COX-enzyme, as compound $6 \mathrm{c}$ shares the same $\mathrm{R}^{3}$ methyl substituent as celecoxib (c.f. Figure 2). In an earlier study by Kanus and co-workers, (Abdellatif et $a l ., 2008)$, the anti-inflammatory activity of a new series of diazen-1-ium-1,2-diolated NO donor ester prodrugs of 1-(4-methanesulfonylphenyl)-5-aryl- $1 H$-pyrazol3-carboxylic acids showed a similar potency profile with regard to the aryl substitution at the 5-position of the pyrazole ring. The AI activities exhibited by the hybrid ester prodrugs $\mathbf{6 a}-\mathbf{c}$ were not determined in this study, as it was previously reported that the same hybrid ester prodrug analogs of aspirin, ibuprofen, and indomethacin exhibited similar AI activities to aspirin, ibuprofen, and indomethacin for comparable $\mathrm{ID}_{50} \mu \mathrm{mol} / \mathrm{kg}$ oral dosage regimens (Velázquez et al., 2007).

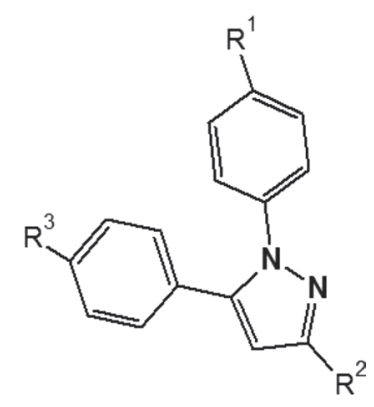

FIGURE 2 - Generic 1,5-diaryl-3-substituted-pyrazole selective COX-2 structure based on the structure of celecoxib $\left(\mathrm{R}^{1}=\right.$ $\mathrm{SO}_{2} \mathrm{NH}_{2}, \mathrm{R}^{2}=\mathrm{CF}_{3}, \mathrm{R}^{3}=\mathrm{CH}_{3}$ ).

\section{Methodology}

\section{Chemistry}

A group of 1-(4-aminosulfonylphenyl)-5-aryl$1 \mathrm{H}$-pyrazol-3-carboxylate esters possessing an $\mathrm{O}^{2}$ - acetoxymethyl-1-( $N$-ethyl- $N$-methylamino $)$ diazen-1ium-1,2-diolate ester moiety $(\mathbf{6} \mathbf{a}-\mathbf{c})$ were synthesized using the reaction sequence illustrated in Scheme 1. Accordingly, the reaction of 2,4-diketo ester 1a-c with (4-aminosulfonylphenyl)hydrazine hydrochloride (2) under reflux in ethanol will provide the corresponding pyrazole esters $(\mathbf{3 a}-\mathbf{c})$. Alkaline hydrolysis of the esters $(\mathbf{3 a}-\mathbf{c})$ with $\mathrm{LiOH}$ yielded the respective acids $(\mathbf{4 a}-\mathbf{c})$. Nucleophilic displacement of the mesyloxy group present in the mesylate (5) by the respective sodium salt of the obtained acids $\mathbf{4 a}-\mathbf{c}$ in hexamethylphosphoramide (HMPA) furnished the target $O^{2}$-acetoxymethyl-1( $N$-ethyl- $N$-methylamino) diazen-1-ium-1,2-diolate 1-(4-amino-sulfonylphenyl)-5-aryl-1H-pyrazol-3carboxylate $(\mathbf{6 a}-\mathbf{c})$.

The starting materials, methyl 2-hydroxy-4-oxo4-aryl-2-butenoate (1a-c) (Abdellatif et al., 2008), were prepared as follows: A solution of diethyloxalate and either acetophenone 1a, 4-fluoroacetophenone 1b, or 4-methylacetophenone 1c in methanol was added dropwise to a solution of $\mathrm{NaOH}$ in $\mathrm{MeOH}$, and the reaction was then refluxed for 2 hours. After cooling to room temperature, the mixture was poured into water acidified with $\mathrm{HCl}$ and extracted with diethylether. The combined extract was washed, dried over $\mathrm{MgSO}_{4}$, and then the solvent was removed in a vacuum. Conversely, (4-aminosulfonylphenyl)hydrazine hydrochloride (2) (Soliman, 1979) and $O^{2}$-acetoxymethyl-1-[N-(2methylsulfonyloxyethyl)- $N$-methylamino] diazen-1-ium1,2-diolate (5) (Velázquez, Knaus, 2004) were prepared according to a literature procedure.

Characterization of the synthesized novel compounds was done using a specific melting point, Fourier-transform infrared (FT-IR), and $1 H$ nuclear magnetic resonance (NMR), which were available at the College of Clinical Pharmacy, King Faisal University.

\section{Statistical analysis}

The results will be expressed as the mean \pm standard error of the mean. The treated groups were compared with the controls to assess any statistically significant differences $(P<0.05)$ using paired Student's $t$-test (IBM SPSS Statistics for Windows, Version 22.0; IBM Corporation, Armonk, NY, USA).

\section{Cyclooxygenase inhibition assay}

The ability of the test compounds to inhibit bovine COX-1 and human recombinant COX-2 was determined using an enzyme-immunoassay (EIA) kit following a previously reported procedure using a 96-well plate (Rao 

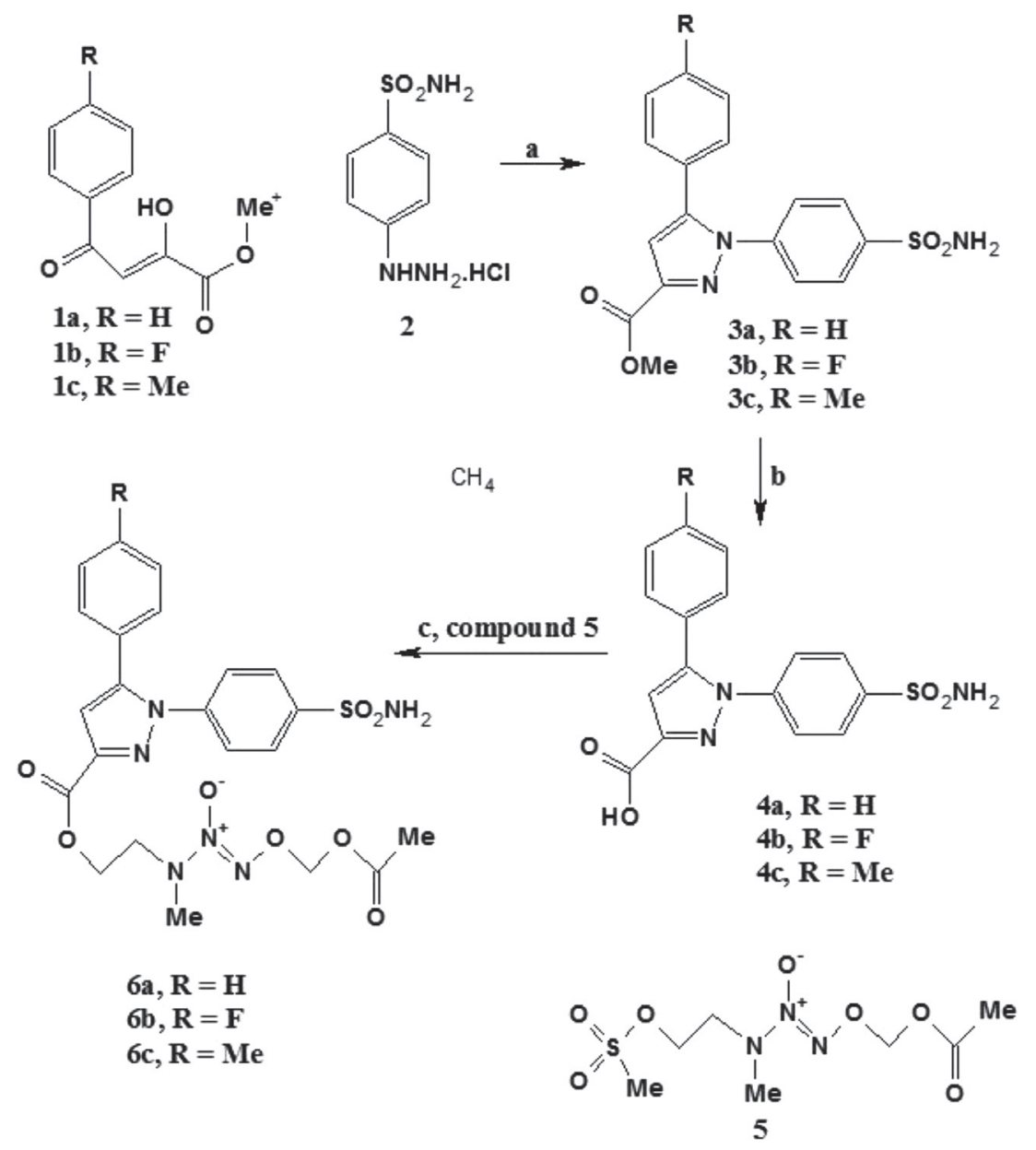

SCHEME 1 - Reagents and conditions: (a) EtOH, reflux, 3 h; (b) THF/MeOH, LiOH (2 M), RT, 15 h; (c) $\mathrm{Na}_{2} \mathrm{CO}_{3}$, hexamethylphosphoramide (HMPA), $25^{\circ} \mathrm{C}, 96 \mathrm{~h}$.

et al., 2003). The procedure is described as follows: (a) $200 \mu \mathrm{L}$ of Ellman's reagent was added to all 96 wells; (b) the plate was covered with a thin film; (c) the plate was incubated at room temperature for 90 minutes in the dark to develop the color; and (d) an ultraviolet (UV) plate reader was used at wavelengths ranging from $405-420 \mathrm{~nm}$.

\section{Nitric oxide release assay}

The test compound was incubated at $37^{\circ} \mathrm{C}$ for 1.5 hours with either $2.4 \mathrm{~mL}$ of a $1.0 \times 10^{-2} \mathrm{mM}$ solution in phosphate buffer at $\mathrm{pH} 7.4$, or with $2.4 \mathrm{~mL}$ of a $1.0 \times 10^{-2} \mathrm{mM}$ solution in phosphate buffer at $\mathrm{pH} 7.4$ to which $901 \mathrm{~L}$ rat serum was added. It was then possible to determine the in vitro NO release via quantification of the nitrite produced by the reaction of $\mathrm{NO}$ with oxygen and water using the Griess reaction. NO release data were acquired for the test compounds $(\mathbf{6 a}-\mathbf{c})$ using the reported procedures (Chowdhury et al., 2010).

\section{In vivo anti-inflammatory assay}

The anti-inflammatory profiles of the test compounds and reference drugs, celecoxib and aspirin, were evaluated using an in vivo carrageenan-induced foot paw edema model, as reported previously (Winter, Risley, Nuss, 1962).

\section{CONCLUSIONS}

A new group of hybrid ester prodrugs (NONOcoxibs) in which an $O^{2}$-acetoxymethyl-1-( $N$-ethyl- $N$ methylamino)diazen-1-ium-1,2-diolate (6a-c) NO-donor moiety is attached directly to the carboxylic acid group of 1-(4-aminosulfonylphenyl)-5-(4-H, 4-F or 4-Mephenyl)-1 $H$-pyrazol-3-carboxylic acids $(\mathbf{4 a - c})$ were synthesized for a comparative biological evaluation. Compound $6 \mathrm{c}$, where $\mathrm{R}=\mathrm{Me}$, displayed the highest AI activity and COX-2 selectivity, but it was still lower than that exhibited by celecoxib. In terms of biological stability, the NO-release studies (a) showed that the NONO-coxib prodrugs $(\mathbf{6 a - c})$ are relatively stable in PBS at $\mathrm{pH} 7$, where the NO release is in the 7.97-8.51 range; (b) highlighted that the $O^{2}$-acetoxymethyl-1-(N-ethyl- $N$ - 
TABLE I - In vivo anti-inflammatory activities for 1-(4-methanesulfonylphenyl)-5-(4-substitutedphenyl)-1H-pyrazol-3-carboxylic acid (4a-c), and percent (\%) nitric oxide release, data for diazeniumdiolate pyrazole esters (6a-c) and in vitro COX-1 and COX-2 inhibition.

\begin{tabular}{|c|c|c|c|c|c|c|c|}
\hline \multirow{2}{*}{ Compound } & \multirow{2}{*}{$\mathbf{R}$} & \multirow{2}{*}{$\begin{array}{c}\text { AI activity } \\
\mathrm{ID}_{50}(\mathrm{mg} / \mathrm{kg})\end{array}$} & \multicolumn{2}{|c|}{$\% \cdot$ NO released ${ }^{\mathrm{b}}$} & \multicolumn{2}{|c|}{$\mathrm{IC}_{50}{ }^{\mathrm{e}}(\mu \mathrm{M})$} & \multirow{2}{*}{ COX-2 S.I. ${ }^{f}$} \\
\hline & & & PBS $^{\mathbf{c}}$ & Serum $^{\mathrm{d}}$ & COX-1 & COX-2 & \\
\hline $4 a$ & $\mathrm{H}$ & $112.4 \pm 7.6$ & - & - & & & \\
\hline $4 b$ & $\mathrm{~F}$ & $110.1 \pm 6.8$ & - & - & & & \\
\hline $4 c$ & $\mathrm{Me}$ & $81.2 \pm 5.9$ & - & - & & & \\
\hline $6 a$ & $\mathrm{H}$ & - & $7.97 \pm 0.62$ & $71.71 \pm 6.3$ & $11.3 \pm 1.1$ & $3.2 \pm 0.27$ & 3.53 \\
\hline $6 b$ & $\mathrm{~F}$ & - & $9.04 \pm 0.81$ & $65.91 \pm 5.8$ & $3.1 \pm 0.25$ & $0.7 \pm 0.06$ & 4.42 \\
\hline $6 c$ & $\mathrm{Me}$ & - & $8.51 \pm 0.72$ & $73.91 \pm 6.7$ & $5.6 \pm 0.49$ & $1.1 \pm 0.98$ & 5.1 \\
\hline Celecoxib & & $12.6 \pm 1.1$ & & & $7.7 \pm 0.63$ & $0.12 \pm 0.01$ & 64.2 \\
\hline Aspirin & & $114.3 \pm 10.9$ & & & $0.3 \pm 0.02$ & $2.4 \pm 0.19$ & 0.13 \\
\hline
\end{tabular}

${ }^{a}$ Inhibitory activity in a carrageenan-induced rat paw edema assay. The results are expressed as the $\mathrm{ID}_{50} \mathrm{value}(\mathrm{mg} / \mathrm{kg})$ at $3 \mathrm{~h}$ after oral administration of the test compound. 'Percent of nitric oxide released based on a theoretical maximum release of $2 \mathrm{~mol}$ of $\mathrm{NO} /$ mol of the dia zen-1-ium-1,2-diolate test compounds (6a-c). The result is the mean value of 3 measurements $(n=3)$ where variation

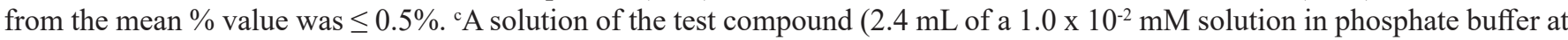
$\mathrm{pH} 7.4)$, was incubated at $37^{\circ} \mathrm{C}$ for $1.5 \mathrm{~h}$. ${ }^{\mathrm{d}} \mathrm{A}$ solution of the test compound $\left(2.4 \mathrm{~mL}\right.$ of a $1.0 \times 10^{-2} \mathrm{mM}$ solution in phosphate buffer at $\mathrm{pH} 7.4$ to which $90 \mu \mathrm{L}$ rat serum had been added), was incubated at $37^{\circ} \mathrm{C}$ for $1.5 \mathrm{~h}$. ${ }^{\mathrm{e}}$ The in vitro test compound concentration required to produce $50 \%$ inhibition of ovine COX-1 or human recombinant COX-2. The result $\left(\mathrm{IC}_{50}, \mu \mathrm{M}\right)$ is the mean of two determinations acquired using the enzyme immune-assay kit (Catalog No. 560131, Cayman Chemicals Inc., Ann Arbor, MI, USA) and the deviation from the mean is $<10 \%$ of the mean value. ${ }^{\mathrm{f}}$ In vitro $\mathrm{COX}-2$ selectivity index $\left(\mathrm{COX}-1-\mathrm{IC}_{50} / \mathrm{COX}-2 \mathrm{IC}_{50}\right)$

methylamino)diazen-1-ium-1,2-diolates (6a-c) undergo extensive cleavage of the terminal acetoxy group by rat serum esterase(s), which is followed by a significant NO release in the $60.51 \%-71.71 \%$ range; and (c) suggested that an alternative linker group to the ester moiety attached directly to the $\mathrm{C}-3$ position of the pyrazole ring is vital to provide more potent AI activity.

\section{EXPERIMENTAL SECTION}

General. Melting points were determined on a Thomas-Hoover capillary apparatus and are uncorrected. Infrared (IR) spectra were recorded as films on $\mathrm{NaCl}$ plates using a Nicolet 550 Series II Magna FT-IR spectrometer. ${ }^{1} H$ NMR spectra were measured on a Bruker AM-300 spectrometer in $\mathrm{D}_{2} \mathrm{O}, \mathrm{CDCl}_{3}$, or DMSO- $\mathrm{d}_{6}$ with TMS as the internal standard, where $J$ (coupling constant) values are estimated in $\mathrm{Hertz}(\mathrm{Hz})$. Microanalyses were performed for C, H, N (Micro Analytical Service Laboratory, Department of Chemistry, University of Alberta, Edmonton, Alberta, Canada) and were within $\pm 0.4 \%$ of the theoretical values. Silica gel column chromatography was performed using a Merck silica gel 60 ASTM (70-230 mesh). All other reagents, purchased from the Aldrich Chemical Company (Milwaukee, WI, USA), were used without further purification. Methyl 2-hydroxy-4-oxo-4-aryl-2-butenoate (1a-c) (Abdellatif et al., 2010), (4-aminosulfonylphenyl) hydrazine hydrochloride (2), (Pommery et al., 2004), and $\mathrm{O}^{2}$-acetoxymethyl-1-[N-(2-methylsulfonyloxyethyl)- $\mathrm{N}$ methylamino]diazen-1-ium-1,2-diolate (5) (Velázquez $\&$ Knaus, 2004) were prepared according to a literature procedure.

General method for preparing methyl 1-(4-aminosulfonylphenyl)-5aryl-1H-pyrazole-3carboxylates $(\mathbf{3 a}-\boldsymbol{c})$. (4-Aminosulfonylphenyl)hydrazine hydrochloride (2) $(0.982 \mathrm{~g}, 4.4 \mathrm{mmol})$ was added to a stirred solution of the dione $\mathbf{1 a}, \mathbf{1 b}$, or $\mathbf{1 c}(4.0 \mathrm{mmol})$ in $50 \mathrm{~mL}$ of EtOH. The mixture was heated to reflux and stirred for 3 hours. After cooling to room temperature, the reaction mixture was concentrated in vacuo. The residue was taken up in EtOAc, washed with water and brine, dried over $\mathrm{MgSO}_{4}$, filtered, and concentrated in vacuo to give 3a-c. Physical and spectral data are listed below.

\section{Methyl 1-(4-aminosulfonylphenyl)-5-phenyl-} 1 H-pyrazole-3-carboxylate (3a). $78 \%$ yield; pale brown powder; IR (film) 3349, $3261\left(\mathrm{NH}_{2}\right), 2960$ (C-H aromatic), 2913 (C-H aliphatic), $1723\left(\mathrm{CO}_{2}\right), 1341,1161$ $\left(\mathrm{SO}_{2}\right) \mathrm{cm}^{-1} ;{ }^{1} \mathrm{H} \mathrm{NMR}\left(\mathrm{CDCl}_{3}+\mathrm{DMSO}_{-} \mathrm{d}_{6}\right) \delta 3.72(\mathrm{~s}, 3 \mathrm{H}$, $\left.\mathrm{OCH}_{3}\right), 6.79(\mathrm{~s}, 1 \mathrm{H}$, pyrazole $\mathrm{H}-4), 6.94\left(\mathrm{~s}, 2 \mathrm{H}, \mathrm{NH}_{2}, \mathrm{D}_{2} \mathrm{O}\right.$ exchangeable), 7.00-7.06 (m, 3H, phenyl H-3, H-4, H-5), 
7.12-7.17 (m, 2H, phenyl H-2, H-6), $7.21(\mathrm{~d}, J=7.2 \mathrm{~Hz}$, $2 \mathrm{H}$, aminosulfonylphenyl H-2, H-6), 7.68 (d, $J=7.2 \mathrm{~Hz}$, 2H, aminosulfonylphenyl $\mathrm{H}-3, \mathrm{H}-5)$.

Methyl 1-(4-aminosulfonylphenyl)-5-(4fluorophenyl)-1H-pyrazole-3-carboxylate (3b). 75\% yield; pale brown powder; IR (film) 3341, $3222\left(\mathrm{NH}_{2}\right)$, 2958 (C-H aromatic), 2922 (C-H aliphatic), $1733\left(\mathrm{CO}_{2}\right)$, $1339,1160\left(\mathrm{SO}_{2}\right) \mathrm{cm}^{-1} ;{ }^{1} \mathrm{H}$ NMR $\left(\mathrm{CDCl}_{3}+\mathrm{DMSO}_{6}\right) \delta$ $3.84\left(\mathrm{~s}, 3 \mathrm{H}, \mathrm{OCH}_{3}\right), 6.90(\mathrm{~s}, 1 \mathrm{H}$, pyrazole $\mathrm{H}-4), 6.93(\mathrm{~s}, 2 \mathrm{H}$, $\mathrm{NH}_{2}, \mathrm{D}_{2} \mathrm{O}$ exchangeable), 6.95-6.99 (m, 2H, fluorophenyl H-2, H-6), 7.13 (m, 2H, fluorophenyl H-3, H-5), 7.31 (dd, $J=8.7,2.2 \mathrm{~Hz}, 2 \mathrm{H}$, aminosulfonylphenyl $\mathrm{H}-2, \mathrm{H}-6), 7.81$ (dd, $J=8.7,2.2 \mathrm{~Hz}, 2 \mathrm{H}$, aminosulfonylphenyl H-3, H-5),

Methyl 1-(4-aminosulfonylphenyl)-5-(4methylphenyl)-1H-pyrazole-3-carboxylate (3c). 89\% yield; white powder; IR (film) 3348, $3256\left(\mathrm{NH}_{2}\right), 2957$ (C-H aromatic), 2918 (C-H aliphatic), $1724\left(\mathrm{CO}_{2}\right), 1337$, $1165\left(\mathrm{SO}_{2}\right) \mathrm{cm}^{-1} ;{ }^{1} \mathrm{H}$ NMR $\left(\mathrm{CDCl}_{3}+\mathrm{DMSO}_{-} \mathrm{d}_{6}\right) \delta 2.28$ $\left(\mathrm{s}, 3 \mathrm{H}, \mathrm{CH}_{3}\right), 3.86\left(\mathrm{~s}, 3 \mathrm{H}, \mathrm{OCH}_{3}\right), 6.89(\mathrm{~s}, 1 \mathrm{H}$, pyrazole $\mathrm{H}-4), 6.90$ (s, 2H, $\mathrm{NH}_{2}, \mathrm{D}_{2} \mathrm{O}$ exchangeable), 7.02 (d, $J=8.1,2 \mathrm{H}$, methylphenyl H-3, H-5), 7.08 (d, $J=8.1$, $2 \mathrm{H}$, methylphenyl H-2, H-6), 7.35 (d, $J=8.5 \mathrm{~Hz}, 2 \mathrm{H}$, aminosulfonylphenyl H-2, H-6), $7.82(\mathrm{~d}, J=8.5 \mathrm{~Hz}, 2 \mathrm{H}$, aminosulfonylphenyl H-3, H-5).

General method for preparing 1-(4-aminosulfonylphenyl)-5-aryl-1 H-pyrazol-3carboxylic acids $(\mathbf{4} \boldsymbol{a}-\boldsymbol{c})$. The appropriate ester $3 \mathrm{a}, 3 \mathrm{~b}$, or $3 \mathrm{c}(1.40 \mathrm{mmol})$, was added to a stirred solution of THF (50 $\mathrm{mL}), \mathrm{MeOH}(50 \mathrm{~mL})$, and $\mathrm{LiOH}(2 \mathrm{M}, 50 \mathrm{~mL})$ and stirred for 15 hours. $\mathrm{NaOH}(1 \mathrm{M}, 200 \mathrm{~mL})$ was added and the mixture was extracted with EtOAc $(200 \mathrm{~mL})$. The aqueous phase was acidified with concentrated $\mathrm{HCl}(38 \mathrm{~mL})$ to a $\mathrm{pH}$ level of 1.0, extracted with EtOAc $(300 \mathrm{~mL})$, dried over $\mathrm{MgSO}_{4}$, and filtered and concentrated under vacuum to give the respective acids $\mathbf{4 a}-\mathbf{c}$, for which physical and spectral data are listed below.

1-(4-Aminosulfonylphenyl)-5-phenyl-1H-pyrazol3-carboxylic acid (4a). 83\% yield; pale brown powder; mp 181-182 ${ }^{\circ} \mathrm{C}$; IR (film) 3628-3271 (OH, $\left.\mathrm{NH}_{2}\right), 3070$ (C-H aromatic), 3005 (C-H aliphatic), $1711\left(\mathrm{CO}_{2}\right), 1312$, $1151\left(\mathrm{SO}_{2}\right) \mathrm{cm}^{-1} ;{ }^{1} \mathrm{H}$ NMR $\left(\mathrm{CDCl}_{3}+\mathrm{DMSO}_{-} \mathrm{d}_{6}\right) \delta 6.68$ (s, 2H, $\mathrm{NH}_{2}, \mathrm{D}_{2} \mathrm{O}$ exchangeable), $6.75(\mathrm{~s}, 1 \mathrm{H}$, pyrazole H-4), 6.96-6.99 (m, 3H, phenyl H-3, H-4, H-5), 7.08$7.12(\mathrm{~m}, 2 \mathrm{H}$, phenyl H-2, H-6), $7.20(\mathrm{~d}, J=8.5 \mathrm{~Hz}, 2 \mathrm{H}$, aminosulfonylphenyl H-2, H-6), $7.64(\mathrm{~d}, J=8.5 \mathrm{~Hz}, 2 \mathrm{H}$, aminosulfonylphenyl H-3, H-5), 11.99 (br. s, 1H, COOH, $\mathrm{D}_{2} \mathrm{O}$ exchangeable); MS $366.05(\mathrm{M}+\mathrm{Na})$.
1-(4-Aminosulfonylphenyl)-5-(4-fluorophenyl)1H-pyrazol-3-carboxylic acid (4b). 65\% yield; pale brown powder; $\mathrm{mp} 213-215^{\circ} \mathrm{C}$; IR (film) 3637-3267 $\left(\mathrm{OH}, \mathrm{NH}_{2}\right), 3069$ (C-H aromatic), 3011 (C-H aliphatic), $1710\left(\mathrm{CO}_{2}\right), 1322,1168\left(\mathrm{SO}_{2}\right) \mathrm{cm}^{-1} ;{ }^{1} \mathrm{H} \mathrm{NMR}\left(\mathrm{CDCl}_{3}+\right.$ DMSO-d $\left._{6}\right) \delta 6.90(\mathrm{~s}, 1 \mathrm{H}$, pyrazole $\mathrm{H}-4), 6.96\left(\mathrm{~s}, 2 \mathrm{H}, \mathrm{NH}_{2}\right.$, $\mathrm{D}_{2} \mathrm{O}$ exchangeable), 7.01-7.05 ( $\mathrm{m}, 2 \mathrm{H}$, fluorophenyl $\mathrm{H}-2$, H-6), 7.13-7.18 (m, 2H, fluorophenyl H-3, H-5), 7.34 (d, $J=8.5 \mathrm{~Hz}, 2 \mathrm{H}$, aminosulfonylphenyl H-2, H-6), 7.81 (d, $J=8.5 \mathrm{~Hz}, 2 \mathrm{H}$, aminosulfonylphenyl H-3, H-5), 12.53 (br. s, $1 \mathrm{H}, \mathrm{COOH}, \mathrm{D}_{2} \mathrm{O}$ exchangeable); MS $384.04(\mathrm{M}+\mathrm{Na})$.

1-(4-Aminosulfonylphenyl)-5-(4-methylphenyl)-1Hpyrazol-3-carboxylic acid (4c). 71\% yield; white powder; $\mathrm{mp} 242-243{ }^{\circ} \mathrm{C}$; IR (film) 3574-3273 $\left(\mathrm{OH}, \mathrm{NH}_{2}\right), 3071$ (C-H aromatic), 3008 (C-H aliphatic), $1716\left(\mathrm{CO}_{2}\right), 1319$, $1156\left(\mathrm{SO}_{2}\right) \mathrm{cm}^{-1} ;{ }^{1} \mathrm{H}$ NMR $\left(\mathrm{CDCl}_{3}+\mathrm{DMSO}_{6} \mathrm{~d}_{6}\right) \delta 2.31$ $\left(\mathrm{s}, 3 \mathrm{H}, \mathrm{CH}_{3}\right), 6.79$ (s, $2 \mathrm{H}, \mathrm{NH}_{2}, \mathrm{D}_{2} \mathrm{O}$ exchangeable), 6.91 (s, $1 \mathrm{H}$, pyrazole $\mathrm{H}-4), 7.05(\mathrm{~d}, J=8.1,2 \mathrm{H}$, methylphenyl H-3, H-5), 7.11 (d, $J=8.1,2 \mathrm{H}$, methylphenyl H-2, H-6), 7.40 (d, $J=8.5 \mathrm{~Hz}, 2 \mathrm{H}$, aminosulfonylphenyl H-2, H-6), 7.84 (d, $J=8.5 \mathrm{~Hz}, 2 \mathrm{H}$, aminosulfonylphenyl H-3, H-5); MS $380.08(\mathrm{M}+\mathrm{Na})$.

General method for preparing of the $\mathrm{O}^{2}$ acetoxymethyl-1-(N-ethyl-N-methylamino) diazen-1-ium1,2-diolate pyrazole esters (6a-c). Sodium carboxylates of the respective acids 5a-c $(\mathrm{R}=\mathrm{H}, \mathrm{F}, \mathrm{Me})$ were prepared in situ by stirring each acid $(2.5 \mathrm{mmol})$ in a suspension of sodium carbonate $(0.27 \mathrm{~g}, 2.5 \mathrm{mmol})$ and HMPA (3.5 $\mathrm{mL}$ ) for $24 \mathrm{~h}$ at $25^{\circ} \mathrm{C}$. A solution of $O^{2}$-acetoxymethyl-1[N-(2-methylsulfonyloxyethyl)- $N$-methylamino]diazen1-ium-1,2-diolate $(5,2.5 \mathrm{mmol})$ in HMPA $(1.5 \mathrm{~mL})$ was then added, and the reaction was allowed to proceed for $72 \mathrm{~h}$ at $25^{\circ} \mathrm{C}$. EtOAc $(30 \mathrm{~mL})$ was added, the mixture was washed with water $(5 \times 15 \mathrm{~mL})$, the organic phase was dried $\left(\mathrm{Na}_{2} \mathrm{SO}_{4}\right)$, and the solvent was removed in vacuo. The residue obtained was purified by silica gel column chromatography using EtOAc /hexane $(2: 1, \mathrm{v} / \mathrm{v})$ as eluent to afford the respective product $6 \mathbf{a}, \mathbf{6 b}$ or $\mathbf{6 c}$ for which the physical and spectral data are listed below.

$O^{2}$-Acetoxymethyl-1-(N-ethyl-N-methylamino) diazen-1-ium-1,2-diolate 1-(4-aminosulfonylphenyl)-5phenyl-1H-pyrazol-3-carboxylate (6a). Yield, 26\%; white powder; mp 63-65 ${ }^{\circ} \mathrm{C}$; IR (film) 3341, $3257\left(\mathrm{NH}_{2}\right), 2982$ (C-H aromatic), 2934 (C-H aliphatic), $1738\left(\mathrm{CO}_{2}\right), 1339$, $1165\left(\mathrm{SO}_{2}\right), 1226,1065(\mathrm{~N}=\mathrm{N}-\mathrm{O}) \mathrm{cm}^{-1} ;{ }^{1} \mathrm{H} \mathrm{NMR}\left(\mathrm{CDCl}_{3}\right)$ $\delta 2.08\left(\mathrm{~s}, 3 \mathrm{H}, \mathrm{COCH}_{3}\right), 3.19\left(\mathrm{~s}, 3 \mathrm{H}, \mathrm{NCH}_{3}\right), 3.85$, (t, $J=5.5$ $\left.\mathrm{Hz}, 2 \mathrm{H}, \mathrm{CH}_{2} \mathrm{~N}\right), 4.59\left(\mathrm{t}, J=5.5 \mathrm{~Hz}, 2 \mathrm{H}, \mathrm{CO}_{2} \mathrm{CH}_{2}\right), 5.09(\mathrm{~s}$, $2 \mathrm{H}, \mathrm{NH}_{2}, \mathrm{D}_{2} \mathrm{O}$ exchangeable), $5.73\left(\mathrm{~s}, 2 \mathrm{H}, \mathrm{OCH}_{2} \mathrm{O}\right), 7.03$ 
(s, 1H, pyrazole H-4), 7.20-7.26 (m, 3H, phenyl H-3, H-4, H-5), 7.37-7.41 (m, 2H, phenyl H-2, H-6), 7.47 (d, $J=6.8$ $\mathrm{Hz}, 2 \mathrm{H}$, aminosulfonylphenyl H-2, H-6), 7.55 (d, $J=6.8$ $\mathrm{Hz}, 2 \mathrm{H}$, aminosulfonylphenyl H-3, H-5), MS 555.12 (M $+\mathrm{Na}$ ); Anal. Calcd for $\mathrm{C}_{22} \mathrm{H}_{24} \mathrm{~N}_{6} \mathrm{O}_{8} \mathrm{~S}: \mathrm{C}, 49.62 ; \mathrm{H}, 4.54 ; \mathrm{N}$, 15.72. Found: C, 49.55; H, 4.62; N, 15.89 .

$\mathrm{O}^{2}$-Acetoxymethyl-1-(N-ethyl-N-methylamino) diazen-1-ium-1,2-diolate 1-(4-aminosulfonylphenyl)-5-(4fluorophenyl)-1H-pyrazol-3-carboxylate (6b). Yield, 21\%; white powder; mp 66-68 ${ }^{\circ} \mathrm{C}$; IR (film) 3360, $3251\left(\mathrm{NH}_{2}\right)$, 2972 (C-H aromatic), 2935 (C-H aliphatic), $1729\left(\mathrm{CO}_{2}\right)$, 1344, $1167\left(\mathrm{SO}_{2}\right), 1221,1062(\mathrm{~N}=\mathrm{N}-\mathrm{O}) \mathrm{cm}^{-1} ;{ }^{1} \mathrm{H}$ NMR $\left(\mathrm{CDCl}_{3}\right) \delta 2.08\left(\mathrm{~s}, 3 \mathrm{H}, \mathrm{COCH}_{3}\right), 3.18\left(\mathrm{~s}, 3 \mathrm{H}, \mathrm{NCH}_{3}\right), 3.84$ (t, $\left.J=5.5 \mathrm{~Hz}, 2 \mathrm{H}, \mathrm{CH}_{2} \mathrm{~N}\right), 4.59\left(\mathrm{t}, J=5.5 \mathrm{~Hz}, 2 \mathrm{H}, \mathrm{CO}_{2} \mathrm{CH}_{2}\right.$ ), $5.05\left(\mathrm{~s}, 2 \mathrm{H}, \mathrm{NH}_{2}, \mathrm{D}_{2} \mathrm{O}\right.$ exchangeable), $5.74\left(\mathrm{~s}, 2 \mathrm{H}, \mathrm{OCH}_{2} \mathrm{O}\right)$, 7.02 (s, 1H, pyrazole $\mathrm{H}-4), 7.08-7.11(\mathrm{~m}, 2 \mathrm{H}$, fluorophenyl H-2, H-6), 7.20-7.24 (m, 2H, fluorophenyl H-3, H-5), 7.46 (d, $J=6.8 \mathrm{~Hz}, 2 \mathrm{H}$, aminosulfonylphenyl H-2, H-6), 7.91 (d, $J=6.8 \mathrm{~Hz}, 2 \mathrm{H}$, aminosulfonylphenyl H-3, H-5); MS 572.97 $(\mathrm{M}+\mathrm{Na})$. Anal. Calcd for $\mathrm{C}_{22} \mathrm{H}_{23} \mathrm{FN}_{6} \mathrm{O}_{8} \mathrm{~S}: \mathrm{C}, 48 ; \mathrm{H}, 4.21$; $\mathrm{N}, 15.27$. Found: $\mathrm{C}, 48.22 ; \mathrm{H}, 4.32 ; \mathrm{N}, 15.38$.

$\mathrm{O}^{2}$-Acetoxymethyl-1-(N-ethyl-N-methylamino) diazen-1-ium-1,2-diolate 1-(4-aminosulfonylphenyl)-5(4-methylphenyl)-1H-pyrazol-3-carboxylate (6c). Yield, $35 \%$; white crystals; mp $142-144{ }^{\circ} \mathrm{C}$; IR (film) 3347 , $3257\left(\mathrm{NH}_{2}\right), 2965$ (C-H aromatic), 2920 (C-H aliphatic), $1733\left(\mathrm{CO}_{2}\right), 1345,1165\left(\mathrm{SO}_{2}\right), 1226,1068(\mathrm{~N}=\mathrm{N}-\mathrm{O}) \mathrm{cm}^{-}$ ${ }^{1} ;{ }^{1} \mathrm{H}$ NMR $\left(\mathrm{CDCl}_{3}\right) \delta 2.09\left(\mathrm{~s}, 3 \mathrm{H}, \mathrm{COCH}_{3}\right), 2.38(\mathrm{~s}, 3 \mathrm{H}$, $\left.\mathrm{CH}_{3}\right), 3.19\left(\mathrm{~s}, 3 \mathrm{H}, \mathrm{NCH}_{3}\right), 3.85,\left(\mathrm{t}, J=5.5 \mathrm{~Hz}, 2 \mathrm{H}, \mathrm{CH}_{2} \mathrm{~N}\right)$, $4.59\left(\mathrm{t}, J=5.5 \mathrm{~Hz}, 2 \mathrm{H}, \mathrm{CO}_{2} \mathrm{CH}_{2}\right), 5.18\left(\mathrm{~s}, 2 \mathrm{H}, \mathrm{NH}_{2}, \mathrm{D}_{2} \mathrm{O}\right.$ exchangeable), $5.74\left(\mathrm{~s}, 2 \mathrm{H}, \mathrm{OCH}_{2} \mathrm{O}\right), 7.00(\mathrm{~s}, 1 \mathrm{H}$, pyrazole H-4), 7.10 (d, $J=7.9 \mathrm{~Hz}, 2 \mathrm{H}$, methylphenyl H-2, H-6), 7.17 (d, $J=7.9 \mathrm{~Hz}, 2 \mathrm{H}$, methylphenyl H-3, H-5), 7.47 (d, $J=6.7 \mathrm{~Hz}, 2 \mathrm{H}$, aminosulfonylphenyl H-2, H-6), 7.88 (d, $J$ $=6.7 \mathrm{~Hz}, 2 \mathrm{H}$, aminosulfonylphenyl H-3, H-5), MS 569.14 $(\mathrm{M}+\mathrm{Na})$. Anal. Calcd for $\mathrm{C}_{23} \mathrm{H}_{26} \mathrm{~N}_{6} \mathrm{O}_{8} \mathrm{~S} \cdot 1 / 2 \mathrm{H}_{2} \mathrm{O}: \mathrm{C}, 50.54$; H, 4.79; N, 15.38. Found: C, 50.78; H, 4.90; N, 15.52.

\section{ACKNOWLEDGE}

We are grateful to the Deanship of Scientific Research, King Faisal University for the financial support of this research (Project No. 150202)

\section{REFERENCES}

Abdellatif KR, Abdelall EK, Bakr RB. Nitric oxide-NASIDS donor prodrugs as hybrid safe anti-inflammatory agents. Curr Top Med Chem. 2017;17(8):941-955.
Abdellatif KR, Chowdhury MA, Dong Y, Knaus EE. Diazen1-ium-1,2-diolated nitric oxide donor ester prodrugs of 1-(4-methanesulfonylphenyl)-5-aryl-1H-pyrazol-3-carboxylic acids: synthesis, nitric oxide release studies and antiinflammatory activities. Bioorg Med Chem. 2008;16(13):65286534.

Abdellatif KRA, Chowdhury MA, Dong Y, Das D, Yu G, Velazquez C, et al. Diazen-1-ium-1,2-diolated nitric oxide donor ester prodrugs of 5-(4-carboxymethylphenyl)-1-(4methanesulfonylphenyl)-3-trifluoromethyl- $1 \mathrm{H}$-pyrazole and its aminosulfonyl analog: Synthesis, biological evaluation and nitric oxide release studies. Bioorgan Med Chem. 2009;17(14):5182-5188.

Abdellatif KRA, Chowdhury MA, Velazquez CA, Huang Z, Dong Y, Das D, et al. Celecoxib prodrugs possessing a diazen-1ium-1,2-diolate nitric oxide donor moiety: Synthesis, biological evaluation and nitric oxide release studies. Bioorgan Med Chem Lett. 2010;20(15):4544-4549.

Abdellatif KRA, Huang Z, Chowdhury MA, Kaufman S, Knaus EE. A diazen-1-ium-1,2-diolated nitric oxide donor ester prodrug of 3-(4-hydroxymethylphenyl)-4-(4methanesulfonylphenyl)-5H-furan-2-one: Synthesis, biological evaluation and nitric oxide release studies. Bioorgan Med Chem Lett. 2011;21(13):3951-3956.

Ahlström MM, Ridderström M, Zamora I , Luthman K. CYP2C9 Structure-metabolism relationships: optimizing the metabolic stability of COX-2 inhibitors. J Med Chem. 2007;50(18):44444452.

Brueggemann LI, Mackie AR, Mani BK, Cribbs LL, Byron KL. Differential effects of selective cyclooxygenase-2 inhibitors on vascular smooth muscle ion channels may account for differences in cardiovascular risk profiles. Mol Pharmacol. 2009;76(5):1053-1061.

Chowdhury MA, Abdellatif KR, Dong Y, Yu G, Huang Z, Rahman M, et al. Celecoxib analogs possessing a N-(4nitrooxybutyl)piperidin-4-yl or N-(4-nitrooxybutyl)-1,2,3,6tetrahydropyridin-4-yl nitric oxide donor moiety: synthesis, biological evaluation and nitric oxide release studies. Bioorg Med Chem Lett. 2010;20(4):1324-1329.

Consalvi S, Biava M, Poce G. COX inhibitors: a patent review (2011-2014). Expert Opin Ther Pat. 2015;25(12):1357-1371. 
Dhawan V, Schwalb DJ, Shumway MJ, Warren MC, Wexler RS, Zemtseva IS, et al. Selective nitros(yl)ation induced in vivo by a nitric oxide-donating cyclooxygenase-2 inhibitor: a NObonomic analysis. Free Radic Biol Med. 2005;39(9):1191-1207.

Dogné JM, Supuran CT, Pratico D. Adverse cardiovascular effects of the coxibs. J Med Chem. 2005;48(7):2251-2257.

Gunter BR, Butler KA, Wallace RL, Smith SM, Harirforoosh S. Non-steroidal anti-inflammatory drug-induced cardiovascular adverse events: a meta-analysis. J Clin Pharm Ther. 2017;42(1):27-38.

Hinz B, Brune K. Cyclooxygenase-2--10 years later. J Pharmacol Exp Ther. 2002;300(2):367-375.

Hrabie JA, Klose JR, Wink DA, Keefer LK. New nitric oxidereleasing zwitterions derived from polyamines. J Org Chem. $1993 ; 58(6): 1472-1476$.

Huang Z, Kaur J, Bhardwaj A, Alsaleh N, Reisz JA, DuMond JF, et al. O2-Sulfonylethyl protected isopropylamine diazen1-ium-1,2-diolates as nitroxyl (HNO) Donors: synthesis, $\beta$-elimination fragmentation, HNO release, positive inotropic properties, and blood pressure lowering studies. J Med Chem. 2012;55(22):10262-10271.

Keefer LK. Progress toward clinical application of the nitric oxide-releasing diazeniumdiolates. Ann Rev Pharmacol Toxicol. 2003;43:585-607.

Konturek PC, Kania J, Burnat G, Hahn EG. NO-releasing aspirin exerts stronger growth inhibitory effect on Barrett's adenocarcinoma cells than traditional aspirin. J Physiol Pharmacol. 2006;57(Suppl 12):15-24.

Kruzliak P, Kovacova G, Pechanova O. Therapeutic potential of nitric oxide donors in the prevention and treatment of angiogenesis-inhibitor-induced hypertension. Angiogenesis. 2013;16(2):289-295.

Kruzliak P, Novák J, Novák M. Vascular endothelial growth factor inhibitor-induced hypertension: from pathophysiology to prevention and treatment based on long-acting nitric oxide donors. Am J Hypertens. 2014;27(1):3-13.

Laine L. The gastrointestinal effects of nonselective NSAIDs and COX-2-selective inhibitors. Semin Arthritis Rheum. 2002;32(Suppl 1):25-32.
Martelli A, Testai L, Anzini M, Cappelli A, Di Capua A, Biava $\mathrm{M}$, et al. The novel anti-inflammatory agent VA694, endowed with both NO-releasing and COX2-selective inhibiting properties, exhibits NO-mediated positive effects on blood pressure, coronary flow and endothelium in an experimental model of hypertension and endothelial dysfunction. Pharmacol Res. 2013;78:1-9.

Martinez EJ, Talley JJ , Boehm TL. No-releasing guanidinecoxib anti-cancer agents, Google Patents; 2014.

Patel HH, Gross GJ. The disputed role of COX-2 in myocardial infarction, is the jury still out? J Mol Cell Cardiol. 2002;34(1):13.

Pommery N, Taverne T, Telliez A, Goossens L, Charlier C, Pommery J, et al. New COX-2/5-LOX inhibitors: apoptosisinducing agents potentially useful in prostate cancer chemotherapy. J Med Chem. 2004;47(25):6195-6206.

Rao PN, Amini M, Li H, Habeeb AG, Knaus EE. 6-Alkyl, alkoxy, or alkylthio-substituted 3-(4-methanesulfonylphenyl)4-phenylpyran-2-ones: a novel class of diarylheterocyclic selective cyclooxygenase- 2 inhibitors. Bioorg Med Chem Lett. 2003;13(13):2205-2209.

Scheen AJ. [Withdrawal of rofecoxib (Vioxx): what about cardiovascular safety of COX-2 selective non-steroidal antiinflammatory drugs?]. Rev Med Liege. 2004;59(10):565-569.

Serafim RA, Primi MC, Trossini GH, Ferreira EI. Nitric oxide: state of the art in drug design. Curr Med Chem. 2012;19(3):386405.

Shinde MG, Modi SJ, Kulkarni VM. Synthesis, pharmacological evaluation, molecular docking and in silico ADMET Prediction of nitric oxide releasing biphenyls as anti-inflammatory agents. App Pharm Sci. 2017;7(10):37-47.

Soliman R. Preparation and antidiabetic activity of some sulfonylurea derivatives of 3,5-disubstituted pyrazoles. J Med Chem. 1979;22(3):321-325.

Thomsen RW, Riis A, Christensen S, McLaughlin JK, Sorensen HT. Outcome of peptic ulcer bleeding among users of traditional non-steroidal anti-inflammatory drugs and selective cyclo-oxygenase- 2 inhibitors. Aliment Pharmacol Ther. 2006;24(10):1431-1438 
Trelle S, Reichenbach S, Wandel S, Hildebrand P, Tschannen B, Villiger PM, et al. Cardiovascular safety of non-steroidal anti-inflammatory drugs: network meta-analysis. BMJ. 2011;342c:7086.

Turini ME, DuBois RN. Cyclooxygenase-2: a therapeutic target. Ann Rev Med. 2002;53:35-57.

Vannini F, MacKessack-Leitch AC, Eschbach EK, Chattopadhyay M, Kodela R, Kashfi K. Synthesis and anticancer potential of the positional isomers of NOSH-aspirin (NBS-1120) a dual nitric oxide and hydrogen sulfide releasing hybrid. Bioorg Med Chem Lett. 2015;25(20):4677-4682.

Velázquez C, Knaus EE. Synthesis and biological evaluation of 1,4-dihydropyridine calcium channel modulators having a diazen-1-ium-1,2-diolate nitric oxide donor moiety for the potential treatment of congestive heart failure. Bioorg Med Chem. 2004;12(14):3831-3840.

Velázquez CA, Chen QH, Citro ML, Keefer LK, Knaus EE. Second-generation aspirin and indomethacin prodrugs possessing an $\mathrm{O}(2)$-(acetoxymethyl)-1-(2-carboxypyrrolidin1-yl)diazenium-1,2-diolate nitric oxide donor moiety: design, synthesis, biological evaluation, and nitric oxide release studies. J Med Chem. 2008;51(6):1954-1961.
Velázquez CA, Praveen Rao PN, Citro ML, Keefer LK, Knaus EE. O2-acetoxymethyl-protected diazeniumdiolatebased NSAIDs (NONO-NSAIDs): synthesis, nitric oxide release, and biological evaluation studies. Bioorg Med Chem. 2007;15(14):4767-4774.

Winter CA, Risley EA, Nuss GW. Carrageenin-induced edema in hind paw of the rat as an assay for antiiflammatory drugs. Proc Soc Exp Biol Med. 1962;111:544-547.

Zarghi A, Javid FS, Ghodsi R, Dadrass OG, Daraei B, Hedayati M. Design, synthesis and biological evaluation of new 5,5-Diarylhydantoin derivatives as selective Cyclooxygenase-2 inhibitors. Sci Pharm. 2011;79(3):449-460.

Zarghi A, Zebardast T, Hajighasemali F, Alipoor E, Daraie B, Hedayati M. Design and synthesis of new 1,3-Benzdiazinan-4one derivatives as selective cyclooxygenase (COX-2) inhibitors. Arch Pharm. 2012;345(4):257-264.

Received for publication on $16^{\text {th }}$ May 2017 Accepted for publication on $04^{\text {th }}$ April 2018 